\title{
Increasing the Budget Costs' Efficiency as a Factor of State Finance Stabilization
}

\author{
O.B. Ivanova ${ }^{1}$, E.D. Kostoglodova ${ }^{2}$, S.S. Galazova ${ }^{3}$, I.G. Prokopenko ${ }^{4}$
}

\begin{abstract}
:
The article stands for comprehensive system approach in increasing the effect and performance of budget costs, providing the stability and long-term sustainability of state finance. In recent times Russia has gone to considerable lengths in introduction of resultoriented budgeting both on federal and regional level. In a similar vein, we could highlight the fact that insufficient conditions are created to increase the efficiency of budget costs management.
\end{abstract}

The research paid much attention to the issues connected with evaluation of budget costs' performance in conditions of implementing the concept of budget consolidation and budget constraints. Authors set number of objectives: studying economic essence of "efficiency" and "performance" of budget expenditures; studying the framework of budget stabilization financial support measures; revealing the methodological approaches in budget cost effect evaluation in the framework of program-target budgeting including the regional level.

The article concludes with the necessity of improving the evaluation system of criterionbased budget costs' management as well as highlighting the condition when the positive effect of program-target budgeting is reached: firstly, solving of methodological problem of measuring the planned (target) and actual results of budget funding; secondly, taking measures of strengthening the real responsibility of state authorities for accomplishment of target indicators

Keywords: stability, budget costs' effect and performance, program-target budgeting.

JEL Classification Codes : H10, H11, H19.

\footnotetext{
${ }^{1}$ Ivanova Olga Borisovna, D.Sc., Professor, Department of finance, Rostov State University of Economics, Rostov-on-Don, Russian Federation, corresponding author, kafedra_Finance@mail.ru

${ }^{2}$ Kostoglodova Elena Dmitrievna, Ph.D., Associate Professor, Department of finance, Rostov State University of Economics, Rostov-on-Don, Russian Federation.

${ }^{3}$ Galazova Svetlana Sergeevna, D.Sc., Professor, North Ossetian State University, Vladikavkaz, Russian Federation.

${ }^{4}$ Prokopenko Irina Grigorievna, postgraduate, Department of finance, Rostov State University of Economics, Rostov-on-Don, Russian Federation.
} 


\section{Introduction}

Stabilization of state finance becomes the key direction of Russian economic policy, proving its efficiency through the times of adjustment to new realities as well as aiming at extension of Russia's balanced development capacity. Solving of the objective needs, on the one hand, providing of economic and financial stability and eliminating the structural macroeconomic misbalances, on the other hand. Shifting to the equilibrium with low inflation and cost of long-term capital will be provided by the introduction of modified version of budget standards and budget consolidation program realization that assumes increasing of budget costs' effect, not increasing of tax burden.

International experience shows that fiscal consolidation enhances the mid-term economic growth through more effective capital and labor allocation, reducing of both uncertainty and real interest rate. Moreover, short-term adjusting of economy is affected by external shocks (like slide in oil prices, financial downturns, domestic markets' disruption) that needs strong correlation of fiscal and credit policy. Therewith the basic principles should comply with the following: all the expenditure commitments should be funded without compromising the macroeconomic stability and foreseeability; changes in management of investments, increasing of fiscal performance, reducing of non-effective costs (both direct and fiscal-integrated). (Minfin, 2016; Pociovalisteanu and Thalassinos, 2008).

The Western literature mainstreams theoretical and empirical research of fiscal incentives and their effect on macroeconomic and financial stability basing on fiscal multipliers' analysis. Calculation of fiscal multipliers as a ratio of macroeconomic variables (GDP, investments) and exogenous ones (total budget revenues and costs) enables the budget planning to highlight priority funding areas, define the directions of increasing the efficiency of fiscal system, and reveal the economic consequences of total budget costs' reduction (Igonina, 2014; Thalassinos and Pociovalisteanu, 2009).

Another main tool of sustainability and stability analysis is aggregate fiscal stress index calculated on the basis of signal state finance indicators (debt sustainability, fiscal gap, national debt rate, budget balance). The index reveals risk factors of budget system's sustainable development and defining of target indicators for longterm budget planning (Vlasov et al., 2013; Liapis et al., 2013).

Implementing of prioritization and budget costs' effect increasing measures should be based on disclosing the appropriate connections between performance and amount of budget funding as well as more clear binding of state programs to the state financial policy objectives, strengthening the project planning principles. Practical implementing of measures noted before includes developing of theoretical and methodological approaches in defining the effect and output. Special attention in foreign references is given to the efficiency indicator as the one of the state costs' 
performance indicators. The total state costs' efficiency indicator used in performance monitoring is calculated as ratio of total budget costs to the goods and services' output i.e. the amount of expenditures per 1 unit of goods or services. The evaluation of efficiency is referred to the public finance issues.

\section{Theoretical, Informational and Empirical, and Methodological Grounds of the Research}

Economic references still have no relevant definition of state costs' performance as well as no clear treatment of costs' efficiency and performance ratio. Both theoretical and applied economic references highlighted two basic models of budget costs' efficiency:

1. economy-efficiency-performance;

2. resource-immediate efficiency-final efficiency.

Later both of the models were merged into the one. Efficiency term includes the following:

- technical efficiency defined as ratio of interim result's cost (commodity/service) and amount of resources spent on its production;

- allocative efficiency that refers to utilizing the resources to meet the greatest citizens' expectations.

Technical efficiency could be commonly connected with production efficiency achieved only at meeting the planned result at minimum costs. It means that public goods are produced at maximum available resource utilization conditions and production gains are impossible without increasing of resource utilization amounts. We mean here that production goes on the verge of production capacity. Allocative efficiency refers to maximal return on limited budget resources. State resources could be utilized for any aims, but the peak efficiency is reached at allocation according to the citizens' preferences. The performance is expressed via various terms, but "achieving the goals" is the most common one.

While studying the efficiency issues, some authors compare it to the rationality. Thus, rational budget resources utilization normally refers to the picking of the best variant of task execution or solving the problem. This is the way when best variant's costs are considered rational. However, rationality indicators are not always coinciding with efficiency ones. Evaluating the effect of state policy on the stability and sustainability of socioeconomic development assumes forming new methodological approaches as a complex of related elements:

1) milestones, targets, objectives;

2) factors, challenges in internal and external environment;

3) resources, techniques, limits, tools; 
4) output and efficiency criteria.

Practical issues of budget costs' efficiency and performance increasing determine the need for development of program budgeting theory and methodology as well as promoting the program budgeting concept through designing state and target programs. Naturally, program-target budgeting is a transfer of competitive resources' allocation techniques to the state finance domain. Development of special planning and monitoring framework is a major tool to increase the costs' efficiency. Proper budget costs measurement needs special indicators. When state costs' efficiency should be evaluated in the context of economy sector, state program, type of service, we should apply 4 basic types of analysis (Schmigol, 2013):

- costs and benefits analysis: comparing of aggregated monetary benefits and budget costs in a certain sector. Applied for proper industries and sectors' budget funds allocation;

- costs and performance analysis: benefits evaluation not in monetary terms but in quantities. Provides the data on certain objective's costs to pick the best variant to succeed;

- costs and utility analysis: modified costs-performance technique to be applied when the multi-result (qualitative and quantitative features) activity is analyzed, and similar results are measured on the weighing expert-based coefficient;

- costs and weighted performance analysis: assessing the non-monetary benefits of budget costs.

Apart from the noted above, some evaluation techniques could be applied in a certain sector. They could consider not only activity features but also social divisions of end service recipient.

\section{Results}

Adopting and introducing the best practices in increasing of budget funds' management efficiency relates to efforts towards the improvement of costs control and productivity gains in state sector of economy. We apply here the OECD term of effective budget resources management (EBRM) as follows: EBRM is a highlyproductive budget process and execution (OECD, 2005). Setting it as a reference point, OECD marks out the number of budget resources management approaches based on the formal budget process data. The first approach deals with openness and presentability. The budget process data is publicly available. The data may include target indicators or performance information. The efficiency here makes a figure for decision making but does not define the amount of funds. Efficiency requirements here are applied at decision making equally to other data that refers to financial policy's macro-limits and political priorities as well.

However, there is no automatic or mechanic connection between objectives and results of budget activity or funding. The efficiency requirement is essential but not 
absolute and has no pre-defined weight in decision making. Final weight coefficients depend on the certain context of policy.

Direct efficiency-funding relation. The approach assumes direct budget performance-dependent resource allocation. The approach is applied in number of OECD countries and includes a set of formulas to represent the region's funding and charges on its budget performance evaluation basis. Most of countries developed the own benchmarking of budget resources management. The practices of budget resources efficiency management are not static or single use ones but has a constant development and improvement (Ketelaar et al., 2007). We offer here a special technique of region's budget resources management efficiency evaluation:

$\operatorname{Ebrm}_{\mathrm{i}, \mathrm{n}}=\left(\mathrm{TBR}_{\mathrm{i}, \mathrm{n}}+\mathrm{CBS}_{\mathrm{i}, \mathrm{n}}\right) /\left(\mathrm{CBM}_{\mathrm{i}, \mathrm{n}}+\mathrm{CNE}_{\mathrm{i}, \mathrm{n}}\right)$,

where

Ebrm $_{\mathrm{i}, \mathrm{n}}$ refers to efficiency of budget resources management of i-region in n-year;

$\mathrm{TBR}_{\mathrm{i}, \mathrm{n}}$ refers to transparency of regional budget resources (i-region in n-year);

$\mathrm{CBS}_{\mathrm{i}, \mathrm{n}}$ is for condition of budget sector (i-region in n-year);

$\mathrm{CBM}_{\mathrm{i}, \mathrm{n}}$ is for budget sector costs (i-region in n-year);

$\mathrm{CNE}_{\mathrm{i}, \mathrm{n}}$ is for cost loading of budget resources management (i-region in n-year).

All the indicators are measured in points from 1 to 5 . The more points has $\mathrm{TBR}+\mathrm{CBS}$ and the less points has $\mathrm{CBM}+\mathrm{CNE}$, the better Ebrm is. The Ebrm ranged from 0,1 to 10 . The more points it has, the more efficiently budget resources are managed (Table 1).

Table 1. Scale of region's budget resources management efficiency

\begin{tabular}{|l|l|l|l|l|l|}
\hline Ebrm range & $\begin{array}{l}\text { Ebrm } \\
<0,5\end{array}$ & $0,5 \leq$ Ebrm $\leq 1$ & $1<$ Ebrm $\leq 4$ & $4<$ Ebrm $\leq 7$ & Ebrm $>7$ \\
\hline $\begin{array}{l}\text { Budget resources } \\
\text { management } \\
\text { efficiency level }\end{array}$ & $\begin{array}{l}\text { critically } \\
\text { low }\end{array}$ & low & medium & high & very high \\
\hline
\end{tabular}

Involving citizens and entrepreneurs into the budget process to solve budget issues increases the efficiency of budget resources utilization. Official papers increasingly include inclusivity principle that assumes involving citizens and public organizations into the budget process (OECD, 2017).

Delegation of key budget process powers to the society allows them to interact with authorities regarding budget planning, execution, and control issues. "Voluntary budgeting" is a crucial tool to increase the budget costs efficiency and measure the output. Its introduction relates to necessity to involve society into the budget process and evaluation of budget-funding projects. Thus, budget efficiency gains are the result of implementing the Voluntary budgeting concept. Moreover, the outputs of 
voluntary budgeting are connected with mid- and long-term projects (Belenchuk et al., 2017).

All these results are evaluated in project funding through number of indicators. So. The indicators are: Number of citizens participated in budget process and social infrastructure projects' evaluation; number of social infrastructure projects presented; number of social projects funded; number of certain program action groups. Mid-term voluntary budgeting indicators should represent positive effect of public participation budgeting, namely: public/entrepreneurs/authorities co-funding dynamics, voluntary budgeting-created infrastructure objects utilization, budget resources efficiency gains caused by effective public control, satisfaction of citizens with the way regional issues are solved including budget transparency ones. Midterm voluntary budgeting includes also citizens' problems prioritization. Public participation allows highlighting regions with social tension to assess the efficiency of voluntary budgeting with quantitative sociological tools.

Long-term effects reveal global, institutional, behavioral fluctuations at the process of voluntary budgeting programs' implementing. They include: boost in public confidence at the process of voluntary budgeting practices, shifts in public selfperception in region's development, local social capital development. Applying the criteria approach in long-term voluntary budgeting could lay the ground for life quality improvement and regional society development as well.

\section{Conclusions and recommendations}

Increasing the efficiency of budget costs management in Russia is aimed at formation of flexible and comprehensive framework associated with basic government strategic control directions that assumes interconnections of strategic and operational efficiency on costs management as well as gains in budget costs transparency (Minfin, 2016; 2017a). Strategic efficiency gains assume also:

- simplification of procedures and implementing of state programs, introduction of project management methods to reach clear socioeconomic goals;

- forming the hard legal-based list of tax and non-tax expenditures and benefits to forecast the benefits and evaluate them as a part of comprehensive budget resources management framework. Such an approach provides the evaluation of tax benefit/expenditure effect with current target state program's indicators as a reference and assigning the authorities responsible for certain benefit or objective;

- creating proper legal basis for providing the state (municipal) services in social sector aimed at development of competition on markets like state (municipal) services;

- providing the operational efficiency of budget costs management assumes gains in efficiency and rapidness of budget execution in the following:

$\checkmark$ improving the order of fiscal support of federal budget funds and development of fiscal letters of credit practices; 
$\checkmark$ optimizing of budget funding targets' changing procedures, improving the financial management quality of primary budget funds' administrators, implementing the single data input principle, continuity of budget data at all budget planning stages;

$\checkmark$ introducing and approval of budget liabilities' limits on the basis of budget appropriations' justification to minimize the mis-planning and increase the transparency and reasonableness of budget appropriations and increase the quality of planning process.

Increasing of budget costs' accountability assumes:

- improving of internal state financial control and audit via new standards development to set unified rules and procedures of control activity and its activity evaluation as well. Such an improvement could unify the control activity via riskoriented approach;

- creating and approval of voluntary budgeting programs and best practices framework as a tool of increasing the efficiency of budget costs. Development and regulation of regions' voluntary budgeting includes development of systemic and conceptual approaches that contain justification of basic objectives, principles, trends of practices of solving local public-participation issues (making budget decisions to increase the budget costs' efficiency, budget transparency, and public control);

- adopting the state administration's accounting and reporting techniques according to the global standards to increase the transparency of financial reports of state (municipal) entities.

\section{References:}

Belenchuk, A., Vagyn, V., Shulga, I. 2017. Initiative budgeting as a tool for budget costs' efficiency increasing. Finance Issues 8, 10-21.

Igonina, L.L. 2014. Evaluation of budget-fiscal policy: retrospective and target-oriented approaches. National interests: priorities and security, 28.

Ketelaar, A., Manning, N. and Turkisch, E. 2007. Performance-based Arrangements for Senior Civil Servants: OECD and other Country Experiences. OECD Working Papers on Public Governance, OECD Publishing, Paris, doi: 10.1787/160726630750.

Liapis, K., Rovolis, A., Galanos, C. and Thalassinos, I.E. 2013. The Clusters of Economic Similarities between EU Countries: A View Under Recent Financial and Debt Crisis. European Research Studies Journal, 16(1), 41-66.

Minfin 2017a. 2016s Ministry of finance activity report and 2017s objectives.

Minfin 2017b. Public declaration of Minfin objectives for 2017.

Minfin 2016. Basic directions of budget policy for 2017 and planned 2018, 2019 http://www.minfin.ru.

OECD 2005. Modernizing Government: The Way Forward, OECD Publishing, Paris.

OECD 2017. Budget transparency toolkit, 67-76. Available at: http://www/oecd/org/gov/budgeting/budget-transparency-toolkit.pdf

Pociovalisteanu, M.D., Thalassinos, I.E. 2008. The beginning and some national 
particularities of liberalism. Metalurgia International, 13(2), Special Issue, 172-177. Romanova, T.F., Andreeva, O.V., Meliksetyan, S.N., Otrishko, M.O. 2017. Increasing of cost efficiency as a trend of public law entities' activity intensification in a public administration sector. European Research Studies Journal, 20(1), 155-161.

Schmigol, N.S. 2013. Modern approaches in state costs' performance evaluation. Financial analytics: issues and solutions, 45 .

Thalassinos, I.E. and Pociovalisteanu, M.D. 2009. The Structural Funds and the Economic and Social Cohesion Process. Annals-Economy Series 1, 313-330.

Vlasov, S., Deryugina, E., Vlasova, Yu. 2013. Study of short- and long-term state finance sustainability in Russia. Economic issues, 3, 33-35. 